ISSN 1693-3699 (Cetak)

Jurnal Komunikasi Pembangunan

ISSN 2442-4102

Juli 2015. Vol.13, No.2

\title{
KEPUASAN SISWA SMA (PESERTA PROGRAM KUNJUNGAN)TERHADAP KINERJA MEDIA PROMOSI INSTITUT PERTANIAN BOGOR
}

\section{(High School Student Gratification (Visit Program Participants) to Performance Promotion Media of IPB $)^{1}$}

\author{
Rio Fatahillah Chita Putra ${ }^{2}$ Pudji Muljono 3 Anna Fatchiya ${ }^{4}$ \\ 1Bagian dari Tesis disampaikan pada seminar hasil penelitian Sekolah Pascasarjana IPB \\ 2 Mahasiswa Pascasarjana IPB Program Studi Komunikasi Pembangunan Pertanian dan Pedesaan \\ 3 Ketua Komisi Pembimbing \\ 4 Anggota Komisi Pembimbing
}

\begin{abstract}
Information has become one of the main needs of the community. Now, the trend of high school students in selecting agricultural major, has decreased. Promotion media of university is very important to improve the information, knowledge, and interests of students in selecting agricultural major in university. This study was conducted to know about the performance of promotion media of IPB. This study used a quantitative approach with survey research method. Data analysis methods used correlational descriptive and gratification discrepancy analysis (T-Test). Data collecting used questionnaire to 112 high school student who participants of "visit program"to IPB. The result shows there any differences of student gratification level toward presentation media, Facebook, and Twitter. Presentation media can use as main media in IPB promotion activity, because based on result of gratification discrepancy, the performances was good and significant. Presentation media can use as mainstream media promotion of IPB.
\end{abstract}

Keyword: gratification, high school students, performance, promotion media, university

\begin{abstract}
ABSTRAK
Informasi telah menjadi salah satu kebutuhan utama masyarakat. Tren siswa dalam memilih perguruan tinggi pertanian menurun. Media Promosi perguruan tinggi sangat penting untuk meningkatkan informasi, pengetahuan dan minat siswa dalam memilih perguruan tinggi pertanian. Penelitian dilakukan untuk mengetahui kinerja media promosi IPB berdasarkan kesenjangan kepuasan. Penelitian ini menggunakan pendekatan kuantitatif dengan metode survei. Analisis data yang digunakan dalam penelitian ini menggunakan analisis deskriptif korelasional, dan analisis kesenjangan kepuasan (T-Test). Pengumpulan data penelitian ini menggunakan kuesioner yang disebarkan ke 112 siswa SMA yang mengikuti "Program Kunjungan" ke IPB. Hasil penelitian ini menunjukan bahwa terdapat perbedaan kesenjangan kepuasan yang ditunjukkan oleh media presentasi, Facebook, dan Twitter. Media presentasi dapat digunakan sebagai media utama dalam promosi IPB karena berdasarkan kesenjangan kepuasan, media inilah yang memiliki kinerja baik dan signifikan. Media presentasi dapat dijadikan media utama IPB dalam melakukan promosi.
\end{abstract}

Kata Kunci : kepuasan, kinerja, media promosi, perguruan tinggi, siswa SMA, 


\section{PENDAHULUAN Latar Belakang}

Informasi telah menjadi salah satu kebutuhan utama masyarakat. Informasi berkembang sejalan dengan berkembangnya teknologi informasi. Masyarakat lebih selektif dalam memilih media mana yang digunakan untuk memperoleh informasi. Berbagai media massa baik cetak maupun elektronik bersaing mendapatkan akses dari khalayak. Hal itu pula yang dilakukan oleh siswa Sekolah Menengah Atas (SMA) di Indonesia dalam memperoleh informasi tentang perguruan tinggi yang akan dipilih.

Tren siswa dalam memilih perguruan tinggi pertanian menurun. Di antara 112 program studi (prodi) yang ditutup di Sulawesi Selatan, tujuh di antaranya adalah ilmu-ilmu pertanian. Penutupan prodi tersebut disebabkan sudah tidak ada lagi peminat serta empat semester berturut-turut sudah tidak lagi melakukan aktivitas proses belajar mengajar. Kenyataan demikian memberi isyarat, bahwa generasi muda yang merupakan anak-anak petani sudah tidak lagi berminat melanjutkan profesi nenek moyang mereka selaku sosok petani tangguh. Penutupan prodi yang terkait dengan ilmu pertanian, seharusnya menyentakkan pihak-pihak yang berkaitan langsung dengan sektor pertanian di daerah ini.(Mustafa, 2009).

Manuwoto et al (2010) menyatakan salah satu hal yang harus dilakukan adalah membuat mahasiswa mendapatkan informasi yang sehingga calon mahasiswa mengenal pertanian melalui promosi. Bagaimana sebuah perguruan tinggi merekrut calon mahasiswanya tidak terlepas dari persoalan program promosi yang harus dipersiapkan secara matang, efektif dan efisien (Muktiyo, 2002). Institut Pertanian Bogor (IPB) sebagai perguruan tinggi berbasis pertanian memiliki tantangan khusus dalam memberikan informasi kepada siswa.

Berbagai media promosi digunakan oleh IPB untuk menunjang program promosi diantaranya media presentasi, brosur, website,
Facebook, dan Twitter. Setiap bulan, IPB juga menerima program kunjungan dimana berbagai sekolah dari seluruh Indonesia melakukan kunjungan ke IPB. Tujuan kunjungan ini adalah memperkenalkan siswa dengan perguruan tinggi dan menambah informasi siswa tentang perguruan tinggi melalui media promosi perguruan tinggi. Penelitian kepuasan siswa SMA terhadap kinerja media promosi perguruan tinggi perlu dilakukan. Media promosi penting sebagai sarana diseminasi informasi tentang perguruan tinggi kepada siswa SMA. Selain itu, perguruan tinggi juga penting untuk mengetahui daftar kepuasan informasi yang penting bagi siswa, penggunaan media promosi, kepuasan yang diperoleh siswa dan kinerja media promosi berdasarkan kesenjangan kepuasan. Hal tersebut diperlukan agar program promosi perguruan tinggi dapat lebih efektif sehigga dapat selektif menggunakan media promosi sesuai dengan kebutuhan siswa SMA.

\section{Tujuan Penelitian} berikut:

Tujuan penelitian ini adalah sebagai

1. Untuk menganalisis hubungan antara karakteristik siswa dengan penggunaan setiap media promosi IPB.

2. Untuk menganalisis hubungan antara karakteristik siswa dengan kinerja setiap media promosi IPB.

3. Untuk menganalisis hubungan antara penggunaan media dengan kinerja media promosi IPB.

4. Untuk menganalisis kinerja media promosi IPB berdasarkan kesenjangan kepuasan.

\section{Hipotesis}

Hipotesis adalah pernyataan atau jawaban tentatif atas masalah dan kemudian hipotesis dapat diverifikasi hanya setelah diuji secara empiris. Tujuan pengujian hipotesis adalah untuk mengetahui kebenaran atau ketidakbenaran, untuk menerima atau menolak jawaban tentatif (Silalahi, 2010). Pada penelitian 
ini, penulis akan menguji hubungan dari beberapa variabel dari penelitan untuk menjawab hipotesis yang telah dirumuskan sebagai berikut :

1. Terdapat hubungan positif yang nyata beda antara karakteristik siswa dengan penggunaan setiap media promosi IPB.

2. Terdapat hubungan positif yang nyata beda antara karakteristik siswa dengan kinerja setiap media promosi IPB berdasarkan kesenjangan kepuasan.

3. Terdapat hubungan positif yang nyata beda antara penggunaan media dengan kinerja media promosi IPB.

4. Terdapat kesenjangan kepuasan terhadap kinerja setiap media promosi IPB

\section{METODE PENELITIAN} Desain, Tempat dan Waktu Penelitian

Penelitian ini dilaksanakan dengan metode survei. Pengumpulan data dilakukan menggunakan kuesioner, wawancara dan data sekunder. Kuesioner disebarkan ke tujuh sekolah yang melakukan kunjungan ke IPB selama Desember 2014. Metode pengambilan sampel yang digunakan adalah purposive sampling.

Jumlah sampel yang diambil adalah 112 orang responden dengan menghitung proporsi pada setiap sekolah yang berkunjung ke IPB. Analisis data dalam penelitian ini menggunakan analisis deskriptif, analisis statistik inferensial dan analisis uji beda ( $t$-test). Pada analisis statistik inferensial digunakan dua metode analisis yakni rank order spearman dan chi square.

\section{HASIL DAN PEMBAHASAN Karakteristik Siswa SMA}

Kegiatan kunjungan siswa SMA ke IPB dilaksanakan dalam rangka menambah pengetahuan siswa tentang IPB. Pihak sekolah juga berharap sedini mungkin siswa dapat menentukan pilihan perguruan tinggi yang akan dituju setelah selesai menempuh pendidikan di SMA. Individu berkomunikasi untuk mendapatkan berbagai macam kepuasan untuk memenuhi kebutuhan mereka (Rubin, Perse, dan
Berbato, 1988). Sebagian besar siswa yang menjadi responden yakni 63 orang $(56.3 \%)$ merupakan perempuan. Sebagian besar responden merupakan siswa kelas 12 yakni 63 orang $(56.3 \%)$.

Pihak sekolah menyatakan bahwa kelas 12 memang sengaja diprogramkan oleh sekolah masing-masing untuk melakukan study tour ke berbagai perguruan tinggi di Indonesia, termasuk IPB. Saat melakukan kunjungan, biasanya SMA-SMA ini melakukan roadshow ke perguruan tinggi di pulau Jawa termasuk IPB guna memperkenalkan siswa kelas 12 tentang perguruan tinggi yang akan mereka pilih. Hal tersebut menunjukkan bahwa SMA di Indonesia melakukan pengenalan perguruan tinggi saat siswa tersebut menginjak kelas 12 dimana sebentar lagi para siswa harus menentukan perguruan tinggi mana yang akan mereka pilih untuk melanjutkan studinya.

Tabel 1 Jumlah dan Persentase Responden Berdasarkan Kategori Karakteristik Siswa

\begin{tabular}{|c|c|c|c|c|}
\hline No. & Karakteristik & Kategorisasi & $\begin{array}{l}\text { Jumlah } \\
\text { Siswa } \\
\text { (orang) }\end{array}$ & $\begin{array}{l}\text { Persentase } \\
(\%)\end{array}$ \\
\hline \multirow[t]{2}{*}{1.} & Jenis Kelamin & Laki-Laki & 49 & 43.8 \\
\hline & & Perempuan & 63 & 56.3 \\
\hline \multirow[t]{3}{*}{2.} & Kelas & 12 & 60 & 53.6 \\
\hline & & 11 & 34 & 30.4 \\
\hline & & 10 & 18 & 16.1 \\
\hline \multirow[t]{5}{*}{3.} & Penghasilan Orang Tua & $>5$ Juta & 34 & 30.4 \\
\hline & & $>4$ juta -5 juta & 21 & 18.8 \\
\hline & & $>3$ juta-4 juta & 15 & 13.4 \\
\hline & & $>2-3$ juta & 20 & 17.9 \\
\hline & & $<2$ juta & 22 & 19.6 \\
\hline \multirow[t]{4}{*}{4.} & $\begin{array}{l}\text { Nilai Rata-Rata Siswa } \\
\text { s/d Semester } 5\end{array}$ & $<7$ & 3 & 2.7 \\
\hline & & $>7-8$ & 59 & 52.7 \\
\hline & & $>8-9$ & 45 & 40.2 \\
\hline & & $>9$ & 5 & 4.5 \\
\hline \multirow[t]{4}{*}{5.} & Jurusan Siswa & IPA & 48 & 42.9 \\
\hline & & IPS & 11 & 9.8 \\
\hline & & Bahasa & 1 & 0.9 \\
\hline & & $\begin{array}{l}\text { Belum Ada } \\
\text { Penjurusan }\end{array}$ & 52 & 46.4 \\
\hline \multirow[t]{4}{*}{6.} & Akreditasi Sekolah & A & 99 & 88.4 \\
\hline & & B & 2 & 1.8 \\
\hline & & $\mathrm{C}$ & 4 & 3.6 \\
\hline & & Tidak Tahu & 7 & 6.3 \\
\hline
\end{tabular}

Hampir setengah dari responden yakni 34 orang (30.4\%) siswa SMA memiliki orang tua yang berpenghasilan lebih dari lima juta rupiah. Hal tersebut menandakan bahwa salah satu alasan siswa tertarik memilih IPB karena 


\begin{tabular}{lllllll}
\hline No. & Kategorisasi & $\begin{array}{l}\text { Presentasi } \\
(\%)\end{array}$ & $\begin{array}{l}\text { Brosur } \\
(\%)\end{array}$ & $\begin{array}{l}\text { Web } \\
(\%)\end{array}$ & $\begin{array}{l}F b \\
(\%)\end{array}$ & $\begin{array}{l}\text { Twitter } \\
(\%)\end{array}$ \\
\hline 1 & Tinggi & 3.58 & 15.18 & 9.82 & 15.18 & 30.36 \\
2 & Cukup & 58.03 & 65.18 & 68.75 & 56.25 & 38.39 \\
3 & Rendah & 38.39 & 19.64 & 21.43 & 28.57 & 31.25 \\
\hline
\end{tabular}

memiliki kecocokan terhadap biaya kuliah di IPB dengan penghasilan orang tua mereka. Dalam hal ini juga menunjukkan bahwa siswa yang berkunjung ke IPB ini merupakan siswa yang orang tuanya memiliki kemampuan finansial yang baik. Sebagian besar dari responden yakni $59(52.7 \%)$ memiliki nilai rapor rata-rata 7-8 hingga semester 5. Dengan nilai rata-rata ini, setiap responden merasa telah memiliki modal nilai untuk mengikuti seleksi di IPB. Hal ini juga menunjukkan bahwa siswa yang ingin mencari informasi tentang IPB merupakan responden siswa yang memiliki kategori nilai yang cukup tinggi.

Sebanyak 48 responden siswa (42.9\%) berasal dari jurusan IPA yang memiliki peluang lebih besar untuk dapat masuk IPB. Semua jalur yang dibuka IPB memprioritaskan siswa dari juruasan IPA untuk masuk IPB. Dengan ini siswa dengan jurusan IPA memiliki peluang besar untuk masuk IPB. Hampir seluruh siswa yang menjadi responden, yakni sebanyak 99 responden siswa $(88.4 \%)$ berasal dari sekolah yang memiliki akreditasi A. Dalam hal ini akreditasi sekolah mempengaruhi kemungkinan siswa untuk diterima di IPB. Siswa yang berasal dari sekolah berakreditasi juga biasanya merupakan sekolah-sekolah favorit di daerah mereka dan biasanya telah mengarahkan siswasiswi mereka untuk masuk ke perguruan tinggi favorit seperti IPB.

\section{Penggunaan Setiap Media Promosi IPB}

Khalayak memiliki keleluasaan untuk memenuhi kebutuhannya melalui berbagai bentuk media untuk mendapatkan kepuasan.Berbagai media promosi yang digunakan oleh IPB. Namun yang merupakan sarana komunikasi antara IPB dengan para siswa SMA terdapat lima media promosi yakni presentasi, brosur, website, Twitter dan Facebook.
Tabel 2 Kategorisasi dan Persentase Responden Berdasarkan Penggunaan Setiap Media Promosi IPB.

Penggunaan media terebut dilihat dari tingkat perhatian siswa sebelum, saat dan setelah menggunakan media promosi IPB, frekuensi, dan durasi siswa mencurahkan waktu mengakses media promosi IPB. Kategorisasi responden siswa dalam menggunakan media promosi IPB termasuk dalam kategori cukup. Para responden siswa baru mengakses media presentasi paling banyak hanya tiga kali yakni saat sekolah melakukan kunjungan ke IPB dan sebaliknya.

Brosur IPB telah diperoleh siswa di berbagai kesempatan namun intensitas membaca brosur masuk dalam kategori cukup karena brosur biasanya hanya dibaca pada saat siswa memilih jurusan mana yang akan dipilih. Para siswa akan lebih terfokus pada alamat admisi.ipb.ac.id yang memuat informasi lengkap tentang IPB. Pendaftaran siswa ke IPB melalui berbagai jalur hanya dapat dipantau melalui website ini. Media sosial baik Facebook maupun Twitter memiliki kelebihan karena sedang tren digunakan oleh para remaja. Pada media sosial ini komunikasi berjalan dua arah, terdapat berbagai daya tarik seperti teks dan visual berupa foto dan video.

\section{Hubungan antara Karakteristik Siswa dengan Penggunaan Setiap Media Promosi IPB}

Salah satu asumsi dari teori Uses and Gratification adalah khalayak aktif dalam memilih media mana yang akan mereka gunakan untuk memenuhi kebutuhannya. Siswa memilih media promosi yang bisa memenuhi kebutuhan informasi. Pada Tabel 3 dapat dilihat hubungan antara karakteristik siswa dengan penggunaan media promosi IPB untuk memenuhi kebutuhan informasi siswa. Karakteristik responden siswa berdasarkan tingkat kelas memiliki hubungan negatif pada penggunaan media presentasi dan memiliki hubungan positif dengan penggunaan website. Semakin tinggi tingkatan kelas, maka semakin rendah penggunaan media presentasi dan semakin tinggi penggunaan website IPB. 
Hal ini karena responden siswa kelas 12 telah terpapar berbagai media promosi IPB. Siswa kelas 12 akan lebih fokus kepada website karena harus memantau proses pendaftaran ke IPB yang telah menggunakan sistem online. Penghasilan orang tua memiliki hubungan negatif dengan media Facebook IPB. Semakin tinggi penghasilan orang tua, maka semakin Tabel 3 Nilai Koefisien Korelasi antara Karakteristik Siswa SMA dengan Penggunaan Setiap Media Promosi IPB. rendah penggunaan Facebook IPB. Hal tersebut karena siswa yang yang memiliki kemampuan dari segi finansial tidak hanya mengakses Facebook. Mereka telah merupakan siswa yang memiliki kemudahan akses terhadap berbagai media promosi IPB.

\begin{tabular}{|c|c|c|c|c|c|c|c|c|c|c|}
\hline \multirow{2}{*}{$\begin{array}{c}\text { Karakteristik } \\
\text { Siswa } \\
\end{array}$} & \multicolumn{2}{|c|}{ Presentasi } & \multicolumn{2}{|c|}{ Brosur } & \multicolumn{2}{|c|}{ Website } & \multicolumn{2}{|c|}{ Facebook } & \multicolumn{2}{|c|}{ Twitter } \\
\hline & $\mathbf{r}_{\mathrm{s}}$ & $\mathbf{z}$ & $\mathbf{r}_{\mathrm{s}}$ & $\mathbf{z}$ & $\mathbf{r}_{\mathrm{s}}$ & $\mathbf{z}$ & $\mathbf{r}_{\mathrm{s}}$ & $\mathbf{z}$ & $\mathbf{r}_{\mathrm{s}}$ & $\mathbf{z}$ \\
\hline Kelas & $-0.317 * *$ & 0.001 & 0.136 & 0.154 & $0.197 *$ & 0.038 & 0.140 & 0.140 & 0.138 & 0.147 \\
\hline Penghasilan Orang Tua & 0.100 & 0.295 & 0.117 & 0.219 & 0.106 & 0.267 & $-0.188 *$ & 0.047 & -.0094 & 0.326 \\
\hline Nilai rata-rata rapor & -0.080 & 0.399 & -0.138 & 0.148 & $-0.248 * *$ & 0.0048 & 0.039 & 0.680 & 0.046 & 0.627 \\
\hline Nilai Akreditasi Sekolah & -0.015 & 0.876 & $0.262 * *$ & 0.005 & 0.071 & 0.454 & 0.055 & 0.561 & 0.146 & 0.124 \\
\hline & $\chi^{2}$ & $\mathbf{p}$ & $\chi^{2}$ & $\mathbf{p}$ & $\chi^{2}$ & $\mathbf{p}$ & $\chi^{2}$ & $\mathbf{p}$ & $\chi^{2}$ & $\mathbf{p}$ \\
\hline Jenis Kelamin & 4.175 & 0.124 & 0.770 & 0.680 & 0.975 & 0.614 & 4.415 & 0.126 & 0.447 & 0.800 \\
\hline Jurusan & 7.013 & 0.320 & 0.915 & 0.989 & 1.420 & 0.965 & 5.285 & 0.508 & 12.371 & 0.054 \\
\hline
\end{tabular}

** Korelasi signifikan pada level $0.01 *$ Korelasi signifikan pada level 0.05

Tabel 4 Nilai Koefisien Korelasi antara Karakteristik dengan Kinerja Setiap Media Promosi IPB.

\begin{tabular}{|c|c|c|c|c|c|c|c|c|c|c|}
\hline \multirow{2}{*}{$\begin{array}{c}\text { Karakteristik } \\
\text { Siswa } \\
\end{array}$} & \multicolumn{2}{|c|}{ Presentasi } & \multicolumn{2}{|c|}{ Brosur } & \multicolumn{2}{|c|}{ Website } & \multicolumn{2}{|c|}{ Facebook } & \multicolumn{2}{|c|}{ Twitter } \\
\hline & $\mathbf{r}_{\mathrm{s}}$ & $\mathbf{z}$ & $\mathbf{r}_{\mathrm{s}}$ & $\mathbf{z}$ & $\mathbf{r}_{\mathrm{s}}$ & $\mathbf{z}$ & $\mathbf{r}_{\mathrm{s}}$ & $\mathbf{z}$ & $\mathbf{r}_{\mathrm{s}}$ & $\mathbf{Z}$ \\
\hline Kelas & $0.208^{*}$ & 0.028 & $0.192 *$ & 0.043 & 0.13 & 0.894 & -0.15 & 0.874 & -0.134 & 0.160 \\
\hline $\begin{array}{l}\text { Penghasilan } \\
\text { Orang Tua }\end{array}$ & $-0.295^{*}$ & 0.02 & 0.20 & 0.838 & $0.234^{*}$ & 0.013 & 0.000 & 1.000 & 0.95 & 0.321 \\
\hline $\begin{array}{l}\text { Nilai rata-rata } \\
\text { rapor }\end{array}$ & $0.214^{*}$ & 0.024 & -0.47 & 0.622 & $-0.208^{*}$ & 0.028 & $-0.301 * *$ & 0.001 & -0.273 & 0.004 \\
\hline Nilai & -0.104 & 0.275 & 0.030 & 0.751 & -0.083 & 0.387 & 0.006 & 0.948 & 0.047 & 0.620 \\
\hline $\begin{array}{l}\text { Akreditasi } \\
\text { Sekolah }\end{array}$ & & & & & & & & & & \\
\hline & $\chi^{2}$ & $\mathbf{P}$ & $\chi^{2}$ & $\mathbf{p}$ & $\chi^{2}$ & $\mathbf{p}$ & $\chi^{2}$ & $\mathbf{p}$ & $\chi^{2}$ & $\mathbf{p}$ \\
\hline Jenis Kelamin & 20.750 & 0.008 & 3.364 & 0.644 & 17.216 & 0.028 & 14.753 & 0.064 & 19.323 & 0.007 \\
\hline Jurusan & 35.252 & 0.065 & 28.734 & 0.17 & $46.398 * *$ & 0.004 & $45.500 * *$ & 0.005 & $41.354 * *$ & 0.005 \\
\hline
\end{tabular}

*** Korelasi signifikan pada level $0.01 \quad *$ Korelasi signifikan pada level 0.05

Nilai akreditasi sekolah memiliki hubungan positif dengan penggunaan brosur. Semakin tinggi akreditasi sekolah, semakin sering siswa membaca brosur IPB. Hal ini karena IPB menjalin hubungan baik dengan guru Bimbingan dan Konseling (BK) pada sekolahsekolah favorit. Setiap tahunnya, IPB selalu mengirimkan brosur terbaru ke sekolah-sekolah favorit sebagai sumber informasi. 
bagaimana hubungan antara karakteristik siswa dengan kinerja setiap media promosi IPB.

Tingkat kelas siswa memiliki hubungan positif dengan penggunaan media presentasi dan brosur. Semakin tinggi kelas siswa maka semakin puas siswa terhadap kinerja media presentasi dan brosur. Siswa kelas 12 merasa puas terhadap informasi pada media presentasi dan brosur karena siswa kelas 12 telah diterpa oleh informasi dari kedua media ini, sehingga intensitasnya menggunakan media ini tinggi. Semakin tinggi penghasilan orang tua maka semakin rendah kepuasan siswa terhadap kinerja media presentasi dan semakin tinggi kepuasan siswa terhadap penggunaan media brosur. Hal ini menunjukkan bahwa siswa dengan akses media lebih banyak akan cenderung memilih media online ketimbang media konvensional. Dalam hal ini siswa memilih media mana yang sesuai dengan kebutuhan mereka. Website IPB dapat memuaskan mereka karena media ini memiliki karakteristik dapat diakses dimana saja dan hal ini sesuai dengan para responden yang berdomisili jauh dari IPB dan memiliki keterbatasan mengakses media presentasi. Nilai rata-rata rapor berhubungan positif dengan penggunaan media presentasi dan negatif dengan penggunaan media online seperti website dan Facebook siswa. Semakin pintar siswa, maka mereka akan merasa puas media online yang dapat diakses dimana saja.

Jurusan siswa memiliki hubungan positif dengan kepuasan siswa terhadap kinerja media presentasi, website dan Twitter. Siswa dengan jurusan IPA akan menggunakan ketiga media tersebut untuk pemenuhan berbagai kebutuhan mereka. Artinya, dengan media presentasi mereka mendapatkan pemaparan dari narasumber secara komprehensif. Website merupakan media mereka untuk mendaftar dimana siswa jurusan IPA memiliki kemungkinan lebih besar diterima dan media Twitter digunakan untuk mempertahankan kontak mereka dengan IPB.

\section{Hubungan antara Penggunaan Media dengan Kinerja Media Promosi IPB}

Setelah siswa menggunakan media promosi, mereka akan mengetahui apakah mereka mendapatkan kepuasan dari kinerja media yang mereka pilih atau tidak. Dalam hal ini, penggunaan media dianalisis berdasarkan tingkat perhatian siswa, frekuensi siswa memperhatikan, dan curahan waktu para siswa terhadap masing-masing media promosi IPB. Tingkat perhatian dilihat dari sebelum, saat dan setelah siswa menggunakan media promosi IPB. Blumler (1979) menyatakan khalayak memiliki aktivitas dimana mereka melakukan selektivitas terhadap media untuk memenuhi kebutuhan mereka. Pada tabel 5 dapat diketahui hubungan antara penggunaan media dengan kinerja media promosi IPB.

Inayah (2012) menyatakan bahwa sebenarnya brosur mampu memberikan informasi tentang keberadaan dan keunggulan masing-masing program studi yang ada di perguruan tinggi, serta informasi mengenai penerimaan pendaftaran mahasiswa baru. Namun brosur hanya dapat diperoleh oleh calon mahasiswa apabila mereka datang ke kampus sehingga brosur belum terdistribusikan secara merata ke calon mahasiswa atau sebaiknya brosur lebih mudah untuk diperoleh.

Tabel 5 Nilai Koefisien Korelasi antara Penggunaan Media dengan Kinerja Media Promosi IPB

\begin{tabular}{llc}
\hline Media & \multicolumn{2}{c}{ Kinerja Media } \\
& rs & $\mathbf{z}$ \\
\hline Presentasi & -0.102 & 0.283 \\
Brosur & $-0.235^{*}$ & 0.013 \\
Website & -0.118 & 0.217 \\
Facebook & 0.042 & 0.662 \\
Twitter & 0.038 & 0.690 \\
** Korelasi signifikan pada level 0.01 & $*$ Korelasi signifikan pada
\end{tabular}
level 0.05

Terdapat hubungan negatif antara penggunaan brosur dengan kinerja media promosi IPB. Hasil korelasi negatif menunjukkan semakin sering membaca brosur IPB, semakin responden siswa tidak puas dengan kinerja media ini. Hal ini karena informasi yang ada di brosur kurang beragam. Dalam hal ini, siswa lebih tertarik kepada media dengan bentuk komunikasi yang sifatnya dua arah. Hal tersebut memungkinkan siswa dapat berinteraksi dengan admin dan mendapatkan informasi yang mereka butuhkan. 


\section{Kinerja Media Promosi IPB Berdasarkan Kesenjangan Kepuasan}

Kinerja media promosi dapat dilihat dari kesenjangan kepuasan siswa setelah menggunakan media tersebut. Pada Tabel 6 diketahui bahwa terdapat kesenjangan kepuasan pada penggunaan media presentasi, Facebook, dan Twitter. Kepuasan yang diperoleh dari penggunaan media presentasi meningkat setelah responden siswa mengaksesnya. Hal ini menunjukkan bahwa kinerja media presentasi baik dan signifikan. Berbeda dengan media Facebook dan Twitter, terdapat penurunan tingkat kepuasan setelah mengakses media Facebook dan Twitter IPB. Hal ini menunjukkan kinerja media Facebook dan Twitter IPB kurang baik dan signifikan. Media presentasi memiliki beberapa kelebihan diantara media yang lain yakni siswa mendapatkan banyak informasi dan mendapatkan banyak pengetahuan karena mereka berkunjung langsung ke IPB.

Dalam presentasi siswa juga bisa melakukan tanya jawab sehingga informasi yang didapatkan siswa menjadi lebih lengkap dan sesuai dengan kebutuhan siswa. Selain itu, muatan informasi yang disampaikan di IPB juga lebih komprehensif dibanding melalui media yang lain. Teori richness media yang diusulkan oleh Daft dan Lengel (1984) juga mengatakan bahwa face to face merupakan komunikasi yang kaya, sedangkan berkomunikasi melalui media adalah sarana komunikasi yang ramping atau miskin.

Tabel 6 Nilai Skor Rata-rata, T-Hitung dan $p$ value Kepuasan terhadap Penggunaan Setiap Media Promosi IPB

\begin{tabular}{|c|c|c|c|c|c|}
\hline $\begin{array}{c}\text { Penggunaan } \\
\text { Media }\end{array}$ & Kepuasan & $\begin{array}{l}\text { Rata- } \\
\text { Rata }\end{array}$ & $\begin{array}{c}\mathrm{T} \\
\text { hitung }\end{array}$ & $\begin{array}{c}p \text {-value } \\
\text { (sig) }\end{array}$ & Kinerja Media \\
\hline \multirow[t]{2}{*}{ Presentasi } & Diharapkan & 2.64 & \multirow[t]{2}{*}{$-5,409$} & \multirow[t]{2}{*}{0,000} & Baik dan \\
\hline & Diperoleh & 2.76 & & & signifikan \\
\hline \multirow[t]{2}{*}{ Brosur } & Diharapkan & 2.77 & \multirow[t]{2}{*}{1,633} & \multirow[t]{2}{*}{0,105} & Kurang baik \\
\hline & Diperoleh & 2.72 & & & $\begin{array}{l}\text { dan tidak } \\
\text { signifikan }\end{array}$ \\
\hline \multirow[t]{3}{*}{ Website } & Diharapkan & 2.75 & \multirow[t]{2}{*}{1,934} & \multirow[t]{2}{*}{0,056} & Kurang baik \\
\hline & Diperoleh & 2.69 & & & $\begin{array}{l}\text { dan tidak } \\
\text { signifikan }\end{array}$ \\
\hline & Diharapkan & 2.65 & 5,193 & 0,000 & Kurang baik \\
\hline Facebook & Diperoleh & 2.45 & & & dan signifikan \\
\hline \multirow[t]{2}{*}{ Twitter } & Diharapkan & 2.70 & \multirow[t]{2}{*}{4,492} & \multirow[t]{2}{*}{0,000} & Kurang baik \\
\hline & Diperoleh & 2.47 & & & dan signifikan \\
\hline
\end{tabular}

Beebe dan Mottet (2009) menyatakan bahwa narasumber mempengaruhi siswa untuk menyampaikan pesan yang dapat mengubah perilaku, kepercayaan, nilai dan kebiasaan para siswa. Luaran alternatif dari public speaking adalah menginisiasi dialog antara narasumber dan khalayak. Selain itu, menjadi media untuk berbagi pandangan atau pikiran (Slagel, 2009). Pada Facebook dan Twitter, responden siswa SMA menyatakan kurang puas. Sebenarnya media ini memiliki potensi karena merupakan media yang sedang digandrungi oleh anak muda saat ini. Namun terlalu cepatnya informasi yang berkembang pada timeline media sosial membuat siswa tidak fokus mengikuti informasi tentang IPB.

\section{SIMPULAN DAN SARAN Simpulan}

Berdasarkan hasil dan pembahasan dapat disimpulkan bahwa :

1. Terdapat hubungan antara beberapa indikator karakteristik ssiwa dengan penggunaan media. Siswa kelas 12 akan cenderung menggunakan website IPB sebagai media informasi karena dibutuhkan untuk segera melakukan pendaftaran ke IPB. Sedangkan siswa kelas 10 dan 11 masih membutuhkan informasi melalui media presentasi. Siswa yang memiliki orang tua berpenghasilan tinggi tidak akan menggunakan Facebook karena pengguna Facebook didominasi oleh kalangan menengah ke bawah. Semakin tinggi rata-rata nilai rapor responden siswa, maka semakin rendah penggunaan website. Hubungan positif pada nilai akreditasi siswa dengan penggunaan media brosur dapat dipahami karena setiap tahunnya IPB mengirimkan brosur kepada sekolah-sekolah yang memiliki peringkat akademik sekolah tinggi dan mayoritas memiliki akreditasi A. Hal tersebut membuat siswa yang bersekolah di sekolah yang terakreditasi A akan tinggi terpapar brosur IPB. 
2. Media presentasi dan brosur jika semakin banyak digunakan maka kinerjanya akan semakin baik untuk memenuhi kebutuhan siswa kelas 12. Siswa yang orang tuanya memiliki penghasilan tinggi akan banyak diterpa media promosi dan memiliki hubungan negatif dengan kinerja media presentasi dan mereka cenderung memilih website. Semakin tinggi nilai rata-rata siswa maka semakin tinggi kepuasan siswa terhadap media presentasi dan semakin rendah terhadap media website dan Facebook. Jurusan siswa memiliki hubungan terhadap kepuasan siswa terhadap kinerja media presentasi, website dan Twitter.

3. Tampilan brosur yang statis membuat siswa merasa bosan jika terlalu sering membacanya. Terdapat hubungan negatif antara penggunaan media brosur IPB dengan kinerja media promosi IPB. Semakin sering responden siswa membaca brosur IPB, semakin tidak puas responden siswa terhadap brosur IPB.

4. Berdasarkan hasil analisis kesenjangan kepuasan, media presentasi IPB memiliki kinerja yang baik. Berdasarkan karakteristiknya, media ini memiliki keunggulan karena komunikasi berlangsung dua arah, dapat mengarahkan siswa secara langsung dan dapat bertukar pikiran dengan siswa melalui tanya jawab.

\section{Saran}

Berdasarkan hasil penelitian diperoleh saran bagi tim promosi IPB yakni :

1. Media presentasi merupakan media kaya akan informasi dan dapat memaparkan informasi secara komprehensif. Keunggulan media ini karena komunikasi berlangsung dua arah dan memiliki peluang untuk dioptimalkan dengan menambah intensitas sesi tanya jawab sehingga siswa dapat melakukan pemenuhan atas kebutuhan informasinya.

2. Media presentasi dapat dijadikan media utama dalam program promosi IPB. Presentasi ini disarankan dilakukan kepada siswa kelas 10 dan 11 sedangkan sosialiasi penggunaan media online dapat dilakukan kepada siswa kelas 12 .

\section{DAFTAR PUSTAKA}

Beebe SA, Mottet TP. 2009. Students and Teachers. 21 Century Communication a Reference Handbook. Sage Publications.

Blumler JG.1979. The Role of Theory in Uses and Gratifications Studies.Sage Publication.

Daft RL, Lengel RH. 1984. Information richness: A new approach to managerial behavior and organizational design. In B. Staw \& L. L. Cummings (Eds.), Research in organizational behaviour. 6: 191-233.

Inayah. 2012. Peranan Promosi dalam Pembentukan Opini Calon Mahasiswa.Jurnal Pengembangan Humaniora.12(3).

Manuwoto S, Gunawan A. Firdaus M. 2010. Fenomena Penurunan Peminat Perguruan Tinggi Pertanian Indonesia. Bogor (ID): IPB Press.

McQuail D. 1987. Teori Komunikasi MFacebookassa-Suatu Pengantar: Edisi Kedua. Dharma A, Ram A, penerjemah. Jakarta (ID): Penerbit Erlangga. Terjemahan dari: Mass Communication Theory: Second Edition.

Muktiyo W. 2002. PR Perguruan Tinggi. Berita Kagama. 14 (XXVI).

Mustafa MY. 2009 Sept. Ironi Studi Ilmu-Ilmu Pertanian di Lumbung Pangan. Tabloid Cerdas, Kopertis Wilayah IX Sulawesi.

Rubin RB, Perse EM, Barbato CA.(1988). Conceptualization and measurement of interpersonal communication motives. Human Communication Research. 14: 602-628.

Silalahi U. 2009. Metode Penelitian Sosial. Bandung (ID): Refika Aditama.

Slagel A. 2009. Public Relation. 21 Century Communication a Reference Handbook. Sage Publications. 
ISSN 1693-3699 (Cetak)

Jurnal Komunikasi Pembangunan

ISSN 2442-4102

Juli 2015. Vol.13, No.2 